\title{
ANALISIS PORTER'S FORCES INDUSTRI MARMER KABUPATEN TULUNGAGUNG SEBAGAI PENENTUAN STRATEGI PENINGKATAN KINERJA PENGRAJIN BATU PIRING KABUPATEN JEMBER
}

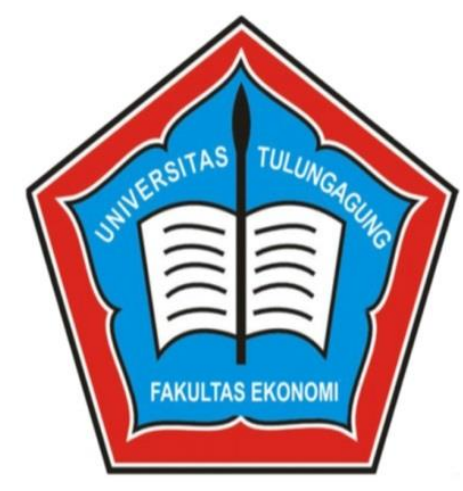

Oleh:

FIFI PERMATASARI (1860301100004)

FERY FATUROSI (1860301100038)

MOCH ALVIN HENDRAWANTO (1860301100061)

DESI FATMAWATI (196031200041)

PRODI AKUNTANSI

FAKULTAS EKONOMI

UNIVERSITAS TULUNGAGUNG

2020 


\begin{abstract}
Abstrak
Penelitian ini bertujuan menganalisis porter's forces industri marmer kabupaten Tulungagung sebagai Penentuan strategi peningkatan kinerja pengrajin batu piring kabupaten Jember. permasalahan mengenai turunnya permintaan batu piring dan tingginya biaya produksi mengakibatkan banyak perusahaan baru dalam industri batu piring handycraft mengalami kondisi yang stagnan bahkan mengalami kebangkrutan. Keberadaan industri pesaing, barang subtitusi seperti batu marmer dan kekuatan bargaining antara pemasok dan pembeli juga menjadi faktor yang sangat diperhatikan untuk merumuskan strategi yang tepat agar tetap dapat bersaing di pasar domestik maupun internasional. Model 5 Porter's Force dalam competitive advantage dan Value Chain Analysis dapat digunakan untuk menentukan strategi terbaik dari efisiensi biaya dan kegiatan produksi, inovasi serta langkah-langkah strategis yang dapat dilakukan melalui identifikasi dan analisis kegiatan industri dari hulu ke hilir. Produktivitas dapat ditingkatkan kembali melalui penerapan strategi bersaing yang dirumuskan berdasarkan model 5 Porter's Forces. Adapun strategi yang dihasilkan dari mini riset ini yakni diperlukan perusahaan menjadi 4 rumusan strategi yaitu (1) strategi struktural yang menentukan posisi perusahaan didalam pasar, (2) strategi generic yang merupakan strategi internal perusahaan meliputi keunggulan biaya, diferensiasi dan fokus pada kegiatan value added konsumen. Kemudian, (3) strategi terhadap pembeli yang meliputi strategi seleksi pembeli melalui target marketing guna mengefisiensi biaya promosi serta mengurangi kekuatan bargaining konsumen dan melalui strategi pembelian guna mengurangi bargaining pemasok. (4) strategi terhadap ancaman produk subtitusi dan new entrant meliputi gerakan ofensif dan defensive yang berguna mempertahankan posisi perusahaan dan membangun hambatan masuk bagi perusahaan pendatang baru.
\end{abstract}

Kata Kunci : Batu Piring, 5 Porter's Force, Value Chain Analysis, Competitive Advantage, Batu Marmer

This study aims to create new strategies and overcome problems regarding the decline in demand for stone plates and the high cost of production resulting in many new companies in the handicraft stone plate industry experiencing stagnant conditions and even bankruptcy. The existence of competing industries, substituted goods such as marble and bargaining power between suppliers and buyers are also factors that are of great concern in formulating the right strategy in order to remain competitive in the domestic and international markets. Model 5 Porter's Force in competitive advantage and Value Chain Analysis can be used to determine the best strategy for cost efficiency and production activities, innovation and strategic steps that can be taken through the identification and analysis of industrial 
activities from upstream to downstream. Productivity can be increased again through the implementation of a competitive strategy formulated based on Porters Forces' model. The strategy resulted from this mini research is that the company needs to form 4 strategies, namely (1) structural strategy that determines the company's position in the market, (2) generic strategy which is the company's internal strategy including cost advantage, differentiation and focus on consumer value added activities. . Then, (3) strategies towards buyers which include buyer selection strategies through target marketing in order to streamline promotional costs and reduce bargaining power of consumers and through purchasing strategies to reduce supplier bargaining. (4) strategies against the threat of substituted and new entrant products include offensive and defensive movements that are useful for defending the company's position and building entry barriers for new entrants.

Keywords: Batu Piring, Porters Force, Value Chain Analysis, Competitive Advantage, Marble Stone

\section{PENDAHULUAN}

\subsection{Latar Belakang}

Tulungagung merupakan penghasil kerajinan marmer dan onix terbesar, dengan hasil produksi sebanyak 24.151 unit per bulan. Marmer, onyx dan batu fosil, deposit marmer berada di Desa Besole Kecamatan Besuki, Desa Ngentrong dan Desa Gamping Kecamatan Campurdarat, serta Desa Sukorejo Kecamatan Bandung, dengan jumlah cadangan $\pm 4.322 .500 \mathrm{~m}^{3}$. Usaha industri kerajinan batu marmer sudah sejak lama ditekuni oleh masyarakat Desa Besole Kecamatan Besuki Kabupatenn Tulungagung. Masyarakat Desa Besole memperkirakan bahwa usaha membuat kerajinan marmer di desa tersebut sudah ada sejak tahun 1960-an (Ilmia, 2017). Munculnya industri di suatu daerah tentunya akan menimbulkan banyak dampak bagi kehidupan masyarakat setempat. Seperti halnya yang terjadi di Desa Besole setelah banyak berdiri industri marmer telah membawa banyak pengaruh untuk kehidupan sosial masyarakat sekitar. Perubahan tersebut merupakan mengarah pada perubahan yang lebih maju dalam beberapa strategi yang bisa di pakai industri batu piring.

Batu piring (lempeng) merupakan batu alam khas Kabupaten Jember yang berasal dari gumuk (Yaqin, 2013). Keberadaan akan 437 gumuk khas Kabupaten Jember dengan 379 gumuk yang belum terpakai merupakan sebuah potensi khusus dari Kabupaten Jember yang perlu dikembangkan secara mendalam (Astutik, 2015). Pertumbuhan komoditas batu piring Jember terus mengalami penurunan hal ini tercermin dari permintaan akan produk batu piring yang semakin menurun tiap tahunnya. Kondisi ini bertolak belakang dengan komoditas batu alam dunia dan 
domestik. Pertumbuhan komoditas batu alam di Kabupaten Tulungagung yang menjadi barang subtitusi batu piring justru mengalami peningkatan. Apabila melihat kondisi tersebut dapat diasumsikan sementara bahwa terdapat permasalahan di dalam aktivitas pengelolaan (strategi) untuk membantu menganalisis industri batu piring Kabupaten Jember.

Permasalahan diduga muncul dari kemampuan produksi dan penyerapan pola permintaan pasar yang juga merupakan strategi sebuah industri. Permasalahan ini juga didukung dengan kondisi permintaan akan batu piring yang semakin menurun tiap tahunnya dikarenakan banyak industri produk subtitusi batu piring yang mulai bermunculan dan mempunyai bargaining yang kuat seperti produk keramik motif batu alam yang mempunyai harga jauh lebih rendah daripada batu piring.

Fenomena ini adalah salah satu bukti nyata bahwa setelah beberapa dekade boom perekonomian dunia, akan ada banyak perusahaan yang kehilangan keunggulan kompetitif dalam persaingan. Kegagalan strategi perusahaan kebanyakan berakar dari ketidakmampuan perusahaan untuk mengkonversikan strategi kompetitif menjadi langkah-langkah spesifik yang diperlukan untuk memperoleh keuntungan dari sebuah keunggulan kompetitif (daya saing). Upaya penentuan strategi yang tepat akan memberikan keuntungan lebih. Penentuan benchmark dapat digunakan sebagai acuan dalam menentukan standar dengan melakukan evaluasi dalam mencapai hasil yang diinginkan (Mould \& Rosin, 2017).

Dengan melihat faktor-faktor dalam teori Porter yang meliputi daya saing, buyer, supplier dan produk subtitusi. Mini riset ini akan mencoba merumuskan strategi baru untuk industri batu piring handycraft Kabupaten Jember dengan melihat strategi yang ada di industri marmer di kabupaten Tulungagung. Dalam menyusun strategi perlu dihubungkan dengan lingkungan perusahaan karena lingkungan menentukan kekuatan dan kelemahan perusahaan, sehingga dapat disusun kekuatan strategi perusahaan (RGM. Prabowo, 2019). Analisis ini akan menggunakan analisis 5 Porter's Force yang didukung dengan alat analisis tambahan berupa analisis struktur dan Value Chain sebagai penentuan usulan strategi kinerja industri yang direkomendasikan. Didukung dengan benchmarking pada industri batu alam di Kabupaten Tulungangung yang merupakan produk subtitusi dan pesaing industri batu piring Kabupaten Jember.

\subsection{Rumusan Masalah}

Berdasarkan deskripsi singkat diatas didapatkan beberapa permasalahan utama dalam penelitian ini meliputi:

1. Bagaimana struktur industri batu alam di Kabupaten Jember terhadap Provinsi Jawa Timur?

2. Bagaimana kegiatan value added pada industri batu alam di Kabupaten Jember dan industri benchmark di Kabupaten Tulungagung? 
3. Bagaimana efisiensi kegiatan produksi batu alam di Kabupaten Jember dan Kabupaten Tulungagung?

4. Bagaimana perumusan strategi baru yang didapat dari industri marmer di Tulungagung untuk industri batu piring handycraft Kabupaten Jember?

\subsection{Tujuan Penelitian}

Adapun tujuan dalam penelitian dalam menjawab beberapa permasalahan utama dalam penelitian ini meliputi:

1. Menganalisis struktur industri batu alam di Kabupaten Jember terhadap Provinsi Jawa Timur.

2. Menganalisis kegiatan value added pada industri batu alam di Kabupaten Jember dan industri benchmark di Kabupaten Tulungagung.

3. Menganalisis efisiensi kegiatan produksi batu alam di Kabupaten Jember dan Kabupaten Tulungagung.

4. Menentukan perumusan strategi baru yang didapat dari industri marmer di Tulungagung untuk industri batu piring handycraft Kabupaten Jember.

\subsection{Manfaat}

Berdasarkan tujuan penelitian adapun manfaat penelitian ini meliputi:

\subsubsection{Bagi industri pengrajin batu piring}

1. Sebagai rumusan strategi usulan perbaikan kinerja industri batu piring di Kabupaten Jember.

2. Sebagai evaluasi kinerja industri batu piring di Kabupaten Jember.

\subsubsection{Bagi Pemerintah Kabupaten Jember}

1. Sebagai evaluasi dan saran regulasi kebijakan untuk meningkatkan produksi batu piring Kabupaten Jember.

\section{TINJAUAN PUSTAKA}

\subsection{Competitive Strategy Porter}

Competitive Advantage digunakan pada ruang lingkup yang lebih kecil yaitu perusahaan. Porter menjelaskan terdapat beberapa faktor yang perlu perhatikan dalam konsep competitive advantage, meliputi New Entrant (ancaman pendatang baru), Bargaining Supplier (kemampuan tawar-menawar pemasok), Buyer (kemampuan tawar-menawar pembeli), Subtitusi(produk pengganti), dan Intensity of Rivaraly (kekuatan pesaing) (Porter, 2008).

\subsection{Analisis Rantai Nilai (Value Chain)}

Value Chain atau rantai nilai adalah rangkaian kegiatan yang dilakukan perusahaan untuk mengolah input menjadi output (Wisdaningrum, 2013). Konsep ini membagi kegiatan perusahaan/industri menjadi dua bagian. Yang pertama adalah aktivitas primer yang terdiri dari Inbound Logistic, Operations (manajemen operasi), 
Outbound Logistic, Marketing and Sales, dan Service. Yang kedua adalah kegiatan pendukung yang terdiri dari Procurement (pengadaan), Technology Development, Human Resource Management (manajemen SDM), dan Firm Infrastructure (Porter, 1985).

\subsection{Analisis Struktur Industri}

Analisis dan diagnosis keuntungan strategi adalah proses dengan mana penyusun strategi memeriksa faktor-faktor keuntungan strategi suatu perusahaan untuk menentukan dimana kekuatan dan kelemahan perusahaan sehingga penyusun strategi dapat memanfaatkan secara efektif kesempatan lingkungan dan menghadapi tantangan lingkungan (RGM. Prabowo, 2019). Fokus analisis struktur industri adalah pada pengenalan ciri pokok yang mendasari suatu industri yang membentuk arena dimana strategi dapat disusun (Porter, 1980). Salah satu alat untuk menganalisis struktur adalah dengan menggunakan konsentrasi rasio. Arsyad \& Kusuma (2014:98) mengutip pendapat Lipczynski, et al. (2005) menyatakan bahwa konsentrasi terdiri dalam 2 jenis yaitu konsentrasi Industri (konsentrasi pasar) dan konsentrasi agregat.

Tabel 2.1 Skema hasil perhitungan rasio konsentrasi (CR)

\begin{tabular}{lll}
\hline Nilai $\boldsymbol{C R}_{4}(\%)$ & Kategori & Interpretasi terkait struktur pasar \\
\hline $\boldsymbol{C} \boldsymbol{R}_{4}=0$ & Minimum & Persaingan sempurna \\
\hline $0<C \boldsymbol{R}_{4}<40$ & Rendah & $\begin{array}{l}\text { Persaingan efektif atau persaingan } \\
\text { monopolistik }\end{array}$ \\
\hline $40 \leq C \boldsymbol{R}_{4}<60$ & Menengah ke bawah & $\begin{array}{l}\text { Perasaingan monopolistic atau oligopoly } \\
\text { longgar }\end{array}$ \\
\hline $60 \leq C \boldsymbol{R}_{4}<90$ & Menengah ke atas & $\begin{array}{l}\text { Oligopoli, ketat atau persuhaan dominan } \\
\text { dengan competitive fringe }\end{array}$ \\
\hline $\boldsymbol{C R _ { 4 } \geq 9 0}$ & Tinggi & $\begin{array}{l}\text { Perusahaan dominan dengan competitive } \\
\text { fringe } \text { atau monopoli efektif (near monopoly) }\end{array}$ \\
\hline $\boldsymbol{C R _ { 4 } = 1}$ & Maksimum & Monopoli sempurna \\
\hline
\end{tabular}

(Sumber: Arsyad \& Kusuma, 2014)

\subsection{Penelitian Terdahulu}

Pada penelitian yang dilakukan oleh Liana Mangifera pada tahun 2015 membahas tentang analisis rantai (value chain) pada produk batik tulis di Surakarta, meneliti keunggulan kompetitif batik dengan tujuan menganalisis rantai nilai dan aktivitas pada industri. Metode yang digunakan adalah kualitatif (wawancara) dan kuantitatif (kuisioner) dengan variabel penelitian meliputi bahan baku, produksi dan penjualan. Penelitian yang dilakukan oleh Yohana Puentes - Rodrigues dkk pada tahun 2017 yang berjudul "Fuelwood value chain analysis in Cassou and Ouagadougou Burkina Faso: From production to consumtion" yang meneliti analisis value chain dengan sudut pandang sosial, ekonomi dan lingkungan dari penggunaan 
kayu bakar dengan tujuan mengetahui rantai nilai penggunaan kayu bakar dengan menggunakan Snowball Sampling dengan alat SPSS-IBM dan Microsoft Excel untuk mencari 5 variabel yaitu tipe dan nomer spesies kayu bakar yang digunakan; lokasi panen, kuantitas dan harga; berbagai macam proses; aktifitas formal; promosi penggunaan kayu bakar. Hasil dari penelitian ini yaitu menjelaskan kegiatan-kegiatan rantai nilai pada objek dengan tambahan variabel lain yaitu gender. Penelitian yang dilakukan oleh Rina Maria Rosales, et., al pada tahun 2017 dengan judul "Value chain analysis and small-scale fisheries management" dengan objek penelitian berupa produk ikan. Permasalahan yang dibahas tentang efesiensi produksi dengan tujuan untuk meningkatkan kualitas dan desain kemasan. Penelitian tersebut menggunakan metode Value Chain Analysis menggunakan data sekunder (kualitatif dan kuantitatif) dan primer (Microsoft Excel) membahas tentang Mapping, product segment, cara produksi, bentuk pemerintahan, hubungan dan kepercayaan pengembang, biaya dan margin distribusi. Hasil dari penelitian yaitu memetakan peta rantai nilai dengan mengaitkan analisis kebijakan, analisis relasis setiap perusahaan, faktor biaya dan margin setiap aktor (pelaku ekonomi).

\subsection{Kerangka konseptual}

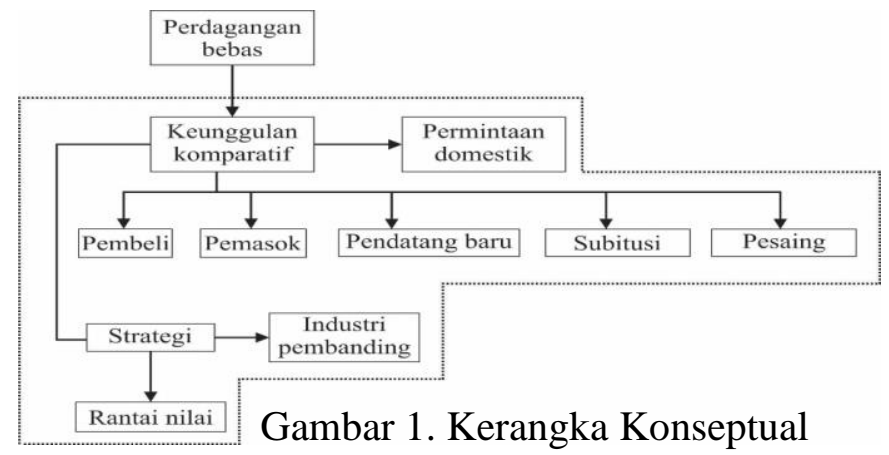

Sebuah studi empiris menyatakan bahwa keberhasilan sebuah perusahaan besar dalam kegiatan ekspor akan ditentukan oleh bagaimana strategi yang mereka gunakan, dimana strategi akan didasarkan pada permintaan pasar dan produktivitas perusahaan mereka sendiri (Aw \& Lee, 2017). Perubahan yang terjadi pada pasar juga menyebabkan pemilihan target pasar merupakan kunci dalam pemasaran sebuah produk (Roosta, Moghaddasi, \& Hosseini, 2017). Adanya perdagangan bebas menyebabkan perluasan pasar semakin besar yang secara langsung berdampak pada peningkatan persaingan antar tiap negara. Persaingan atau yang biasa disebut dengan keunggulan kompetitif akan mendorong pertumbuhan suatu industri dengan meningkatnya permintaan akibat strategi/ keunggulan kompetitif yang tinggi. Konsep keunggulan kompetitif disini dipengaruhi oleh beberapa faktor meliputi 5 komponen kekuatan porter (Porter's Force) yaitu pemasok, pembeli, industri pendatang, industri pesaing dan produk subtitusi. Dengan menggunakan asumsi dasar bahwa strategi perusahaan industri batu alam akan memberikan lebih banyak keuntungan pada perusahaan, keberhasilan suatu strategi akan meningkatkan permintaan (potensi pasar) dan produktivitas sebuah industri. 


\section{METODE PENELITIAN}

Penelitian ini menggunakan pendekatan deskriptif kualitatif yang berfokus pada perumusan strategi baru untuk perusahaan industri batu piring handycraft Kabupaten Jember sesuai dengan indikator yang diperoleh dari studi literatur dan penelitian terdahulu. Uji keabsahan data dilakukan dengan menggunakan uji triangulasi.

\subsection{Populasi dan Sampel}

Terdapat 4 kategori populasi dan sampel pada penelitian ini yaitu terdiri dari populasi seluruh perusahaan Industri batu piring handycraft Kabupaten Jember dan Kabupaten Tulungagung, pemasok dan pembeli bagi industri batu piring handycraft Kabupaten Jember. Teknik sampling yang digunakan adalah snowball.

\subsection{Sumber Data dan Teknik Pengambilan Data}

Sumber data yang digunakan adalah data primer terkait aktivitas kinerja industri dan data sekunder terkait komoditas batu alam tingkat kabupaten dan provinsi 2011 2016. Teknik pengambilan data yang digunakan meggunakan teknik wawancara dan observasi.

\subsection{Analisis Data}

Penelitian ini akan menganalisis strategi dan posisi industri pada persaingan pasar yang akan dianalisis menggunakan analisis struktur industri dan metode rantai nilai (Value Chain). Data dianalisis menggunakan teknik wawancara terstruktur sehingga menghasilkan data matrik tabel sederhana untuk merumuskan starategi penentuan kompetisi yang baik pada industri.

\subsection{Alur Penelitian}

Penelitian akan dimulai dengan mencari data sekunder untuk menentukan struktur industri serta menentukan kriteria pertanyaan sebagai pengukur kegiatan primer dan skunder dalam kinerja industri, selanjutnya proses pemilihan sampel dilakukan sesuai dengan metode yang telah ditentukan, kemudian wawancara dilakukan pada industri yang menjadi obyek penelitian untuk mengidentifikasi aktivitas industri, data Gambar 2. Alur Penelitian komoditas, hasil wawancara dan dokumentasi akan disimpan. Selanjutnya data akan dipilah menjadi dua. Data komoditas batu alam yang akan dianalisis menggunakan CR4 dan data wawancara yang akan dianalisis menggunakan metode value chain. 
Gabungan kedua hasil analisis akan disesuaikan dengan konsep 5 Porter's Force untuk membentuk rumusan strategi baru.

\section{HASIL YANG DICAPAI DAN POTENSI KHUSUS}

\subsection{Struktur Pasar Industri}

\subsubsection{Berdasarkan Rasio Konsentrasi Pasar}

Berdasarkan rasio konsentrasi pasar (CR4), share dari industri batu piring adalah sebesar $0 \%$ yang berarti bahwa industri batu piring handycraft Kabupaten Jember memiliki struktur pasar persaingan sempurna. Secara umum, industri batu alam, seperti industri batu piring Kabupaten Jember memiliki struktur pasar persaingan sempurna dimana tingkat competitiveness antar perusahaan rendah. Tabel analisis terlampir pada lampiran 2 pada tabel 4.1 .

Tabel 4.1 Rasio Konsentrasi Pasar Batu Piring

\begin{tabular}{|c|c|}
\hline \multicolumn{2}{|c|}{2014 (dalam Ton) } \\
\hline Bahan bakar mineral & Batu piring \\
\hline $1,011,169,270.00$ & $1,800.00$ \\
\hline Share & 0.00000178 \\
\hline Kategori & Rendah \\
\hline
\end{tabular}

Sumber : BPS (data yang telah diolah)

\subsubsection{Berdasarkan Karakteristik Pasar}

Menurut hasil wawancara, dalam memasuki industri batu piring handycraft Kabupaten Jember diperlukan modal yang cukup besar, tenaga kerja yang terampil dan pengalaman yang memadai untuk dapat menembus pasar domestik maupun pasar internasional. Hal ini mengindikasikan adanya barrier to entry yang tinggi untuk memasuki pasar namun memiliki free to exit yang tinggi pula untuk pengusaha keluar dari pasar tanpa mempengaruhi harga produk dipasaran. Output yang dihasilkan berupa komoditas sehingga secara fisik memiliki kualitas fisik yang sama (homogen) namun terdapat diferensiasi kualitas produk berupa kerataan, ketebalan dan service terhadap pembeli.

\subsubsection{Identifikasi Struktur Pasar Industri}

Berdasarkan konsentrasi pasar dan karakteristik industri, industri batu piring handycraft Kabupaten Jember memiliki struktur pasar monopolistik dimana tingkat persaingan rendah dan diferensiasi produk terdapat pada kualitas produk dan service/ layanan terhadap pembeli berupa ketepatan waktu pengiriman dan kesesuaian produk terhadap pesanan. Industri batu piring merupakan industri batu alam yang 
terfragmentasi yang disebabkan oleh perbedaan jenis batu antar wilayah dan dapat teridentifikasi dari perbandingan jumlah perusahaan skala kecil yang lebih besar daripada perusahaan skala besar (Porter, 1980).

\subsection{Identifikasi Kegiatan Value Chain}

\subsubsection{Identifikasi Kegiatan Value Chain Pada Industri Batu Piring Handycraft Jember (C.V Rahmat)}

CV. Rahmat merupakan perusahaan perseorangan yang bergerak dibidang pembuatan produk batu piring (hansycraft). Perusahaan tersebut terletak di Jl. Raya Biting No. 17 Arjasa, Kabupaten Jember. Perusahaan tersebut telah berdiri sejak tahun 2009, hingga saat ini pangsa pasarnya telah menjangkau kawasan internasional. Dalam proses identifikasi kegiatan yang ada pada CV. Rahmat, penulis membagi ke dalam beberapa kategori sebagai kegiatan utama mulai dari proses mendapatkan bahan baku, pemrosesan bahan baku hingga barang jadi, proses penjualan, serta distribusi produk dan pelayanan pada pelanggan. Sedangkan dari kategori aktivitas pendukung yang ada dalam perusahaan CV. Rahmat meliputi pengembangan infrastruktur perusahaan, pengelolaan sumber daya manusia, hingga penyediaan bahan baku dan peralatan produksi.

Tabel 4.2. Komposisi Biaya pada Aktivitas Nilai dengan Pendekatan Value Chain

\begin{tabular}{|c|c|c|}
\hline No & Keterangan & Biaya Produksi per 285 meter $^{2}$ \\
\hline \multicolumn{3}{|c|}{ Aktivitas Primer } \\
\hline \multirow[t]{2}{*}{1} & Inbound Logistic & \\
\hline & Biaya Pengecekan Bahan Baku & 150,000 \\
\hline \multirow[t]{5}{*}{2} & Operation & \\
\hline & Biaya Pengemasan & \\
\hline & Peti Kayu & $3,000,000$ \\
\hline & Jaring & $3,500,000$ \\
\hline & Tali & $1,000,000$ \\
\hline \multirow[t]{5}{*}{3} & Outbond Logistic & \\
\hline & Biaya BBM & $2,000,000$ \\
\hline & Biaya Pengiriman & \\
\hline & Jember- FoB shipping Surabaya & $12,000,000$ \\
\hline & Surabaya-Jepang & $9,450,000$ \\
\hline \multirow[t]{2}{*}{4} & Marketing and Sales & \\
\hline & Fee Promotor Informal (5\%) & $2,483,561$ \\
\hline \multirow[t]{3}{*}{5} & Services & \\
\hline & $\begin{array}{l}\text { Biaya Ganti Rugi atas Ketidaknyamanan } \\
\text { Pelayanan }\end{array}$ & $2,700,000$ \\
\hline & Total Biaya Aktivitas Primer & $36,283,561$ \\
\hline
\end{tabular}




\begin{tabular}{|c|c|c|}
\hline \multicolumn{3}{|c|}{ Aktivitas Pendukung } \\
\hline \multirow[t]{2}{*}{1} & Procurement & \\
\hline & Biaya Pembelian Peralatan & 500,000 \\
\hline 2 & Technology Development & - \\
\hline \multirow[t]{6}{*}{3} & Human Resource Management & \\
\hline & Gaji Sekretaris & 500,000 \\
\hline & Gaji Manajer & $1,250,000$ \\
\hline & Gaji Pengrajin (10.000/ meter $\left.^{2}\right)$ & $2,850,000$ \\
\hline & Biaya Tunjangan Konsumsi & $1,400,000$ \\
\hline & Biaya Tunjangan BPJS & 325,000 \\
\hline \multirow[t]{3}{*}{4} & Firm Infrastructure & \\
\hline & Biaya Pajak Penjualan (1\%) & 496,712 \\
\hline & Biaya Penyusutan Kendaraan & 833,333 \\
\hline \multicolumn{2}{|r|}{ Total Biaya Aktivitas Sekunder } & $8,155,045$ \\
\hline
\end{tabular}

Sumber: C.V Rahmat, 2018

Tabel 4.3 Cost Driver pada Setiap Aktivitas Nilai Produksi $285 \mathrm{~m}^{2}$

\begin{tabular}{|c|c|c|c|}
\hline No & Aktivitas & Cost Driver & Nilai \\
\hline 1 & Pengangkutan Bahan Baku & $\begin{array}{l}\text { Jumlah Penerimaan Bahan } \\
\text { Baku }\end{array}$ & $7,000,000$ \\
\hline 2 & Pengawasan & Jam Tenaga Kerja Langsung & 50,000 \\
\hline 3 & $\begin{array}{l}\text { Pemeriksaan dan Pemilahan } \\
\text { Bahan Baku }\end{array}$ & Jam Tenaga Kerja Langsung & 100,000 \\
\hline 4 & Penyimpanan Bahan Baku & Jumlah Persediaan Bahan Baku & - \\
\hline 5 & Penjualan & Jumlah Pesanan Produk & $49,671,225$ \\
\hline 6 & Pengemasan & Jumlah Produk yang dikirim & $6,500,000$ \\
\hline 7 & Pengiriman & Jumlah Produk yang dikirim & $12,000,000$ \\
\hline 8 & Pemrosesan Pesanan & Jumlah Pesanan Penjualan & - \\
\hline 9 & Penanganan Keluhan & Jumlah Komplain Konsumen & $2,700,000$ \\
\hline 10 & Promosi nonformal & Jumlah Konsumen Baru & $2,483,561$ \\
\hline 11 & Pemeriksaan Kualitas Produk & Jam Pemeriksaan & 150,000 \\
\hline Suml & ar: C.V Rahmat, 2018 & & \\
\hline
\end{tabular}

\subsubsection{Identifikasi Kegiatan Value Chain Pada Industri Marmer Tulungagung (Home Industry) \\ "PRIMA" merupakan Home Industry yang bergerak dibidang pembuatan produk batu marmer. Perusahaan tersebut terletak di kecamatan Campurdarat}


kabupaten Tulungagung. Perusahaan tersebut telah berdiri sejak tahun 1982, hingga saat ini pangsa pasarnya telah mencangkau kawasan internasional.

Dalam proses identifikasi kegiatan yang ada pada industri marmer Tulungagung, penulis membagi ke dalam beberapa kategori sebagai kegiatan utama mulai dari proses mendapatkan bahan baku, pemrosesan bahan baku hingga barang jadi, proses penjualan, serta distribusi produk dan pelayanan pada pelanggan. Sedangkan dari kategori aktivitas pendukung yang ada dalam perusahaan tersebut meliputi pengembangan infrastruktur perusahaan, pengelolaan sumber daya manusia, hingga penyediaan bahan baku dan peralatan produksi.

Tabel 4.6 Komposisi Biaya pada Aktivitas Nilai dengan Pendekatan Value Chain

\begin{tabular}{|c|c|c|}
\hline No & Keterangan & Biaya Produksi per $\mathbf{3 0 0}$ meter \\
\hline \multicolumn{3}{|c|}{ Aktivitas Primer } \\
\hline \multicolumn{3}{|c|}{1 Inbound Logistic } \\
\hline & Biaya Pengecekan Bahan Baku & - \\
\hline \multicolumn{3}{|c|}{2 Operation } \\
\hline & Biaya Pengemasan & 9.000 .000 \\
\hline \multirow[t]{6}{*}{3} & Outbond Logistic & \\
\hline & Biaya Penyimpanan & 1.000 .000 \\
\hline & Biaya BBM & 1.250 .000 \\
\hline & Biaya Pengiriman & \\
\hline & Tulungagung - Ekspedisi Jakarta & 1.750 .000 \\
\hline & Ekspedisi Jakarta - Eropa & - \\
\hline \multirow[t]{2}{*}{4} & Marketing and Sales & \\
\hline & Fee Promotor Informal (5\%) & - \\
\hline \multirow[t]{4}{*}{5} & Services & \\
\hline & Biaya Ganti Rugi atas Ketidaknyamanan & \\
\hline & Pelayanan & - \\
\hline & Total Biaya Aktivitas Primer & 13.000 .000 \\
\hline \multicolumn{3}{|c|}{ Aktivitas Pendukung } \\
\hline \multirow[t]{2}{*}{1} & Procurement & \\
\hline & Biaya Pembelian Peralatan & 2.260 .000 \\
\hline 2 & Technology Development & - \\
\hline \multirow[t]{5}{*}{3} & Human Resource Management & \\
\hline & Gaji Sekretaris & 350.000 \\
\hline & Gaji Manajer & 900.000 \\
\hline & Gaji Pengrajin (per hari Rp 90.000,-) & 2.700 .000 \\
\hline & Biaya Tunjangan & 2.300 .000 \\
\hline
\end{tabular}


4 Firm Infrastructure

Biaya Pajak Penjualan (1\%)

496.712

Biaya Penyusutan Mesin

2.000 .000

Biaya Penyusutan Kendaraan

883.333

Total Biaya Aktivitas Sekunder

11.890 .045

Sumber: Home Industry Tulunggagung 2020, diolah oleh penulis

Tabel 4.7 Cost Driver pada Setiap Aktivitas Nilai Produksi $300 \mathrm{~m}^{2}$

\begin{tabular}{|rllr|}
\hline No & \multicolumn{1}{c}{ Aktivitas } & \multicolumn{1}{c|}{ Cost Driver } & Nilai \\
\hline 1 & Pengangkutan Bahan Baku & Jumlah Penerimaan Bahan Baku & 24.000 .000 \\
2 & Pengawasan & Jam Tenaga Kerja Langsung & - \\
& Pemeriksaan dan Pemilahan & & \\
3 & Bahan Baku & Jam Tenaga Kerja Langsung & - \\
4 & Penyimpanan Produk Jadi & Jumlah Persediaan Bahan Baku & 1.000 .000 \\
5 & Penjualan & Jumlah Pesanan Produk & 90.000 .000 \\
6 & Pengemasan & Jumlah Produk yang dikirim & 9.000 .000 \\
7 & Pengiriman & Jumlah Produk yang dikirim & 3.000 .000 \\
8 & Pemrosesan Pesanan & Jumlah Pesanan Penjualan & - \\
9 & Penanganan Keluhan & Jumlah Komplain Konsumen & - \\
10 & Promosi nonformal & Jumlah Konsumen Baru & - \\
11 & Pemeriksaan Kualitas Produk & Jam Pemeriksaan & - \\
\hline
\end{tabular}

Sumber: Home Industry Tulunggagung 2018, diolah oleh penulis

Tabel 4.8 Analisis Aktivitas

\begin{tabular}{|llc|}
\hline No & \multicolumn{1}{c|}{ Aktivitas } & Jenis Aktivitas \\
\hline 1 & Pengangkutan Bahan Baku & BVA \\
2 & Pengawasan & BVA \\
3 & Pemeriksaan dan Pemilahan Bahan Baku & RVA \\
4 & Penyimpanan Produk Jadi & NVA \\
5 & Penjualan & RVA \\
6 & Pengemasan & RVA \\
7 & Pengiriman & RVA \\
8 & Pemrosesan Pesanan & RVA \\
9 & Penanganan Keluhan dan Ganti Rugi & RVA \\
10 & Promosi nonformal & RVA \\
11 & Pemeriksaan Kualitas Produk & NVA \\
\hline
\end{tabular}

Sumber: Home Industry Tulunggagung 2018, diolah oleh penulis.

Gambar 1.1 Value Chain CV. Rahmat 


\begin{tabular}{|c|c|c|c|c|c|}
\hline Firm Infrastruktur & \multicolumn{5}{|c|}{ : Peralatan produksi (mesin potong, bor kecil, mesin bubut, mesin poles, dan gergaji berbagai ukuran). } \\
\hline $\begin{array}{l}\text { Human Resource } \\
\text { Management }\end{array}$ & \multicolumn{5}{|c|}{$\begin{array}{l}\text { Tenaga kerja terdiri dari tenaga kerja langsung dan tenaga kerja tidak langsung ( bagian administrasi, } \\
\text { pengawas bahan baku, dan supervisor). }\end{array}$} \\
\hline $\begin{array}{l}\text { Technology } \\
\text { Development }\end{array}$ & \multicolumn{5}{|c|}{ : Menggunakan peralatan mo dem dengan tenaga listrik } \\
\hline Procurement & \multicolumn{5}{|c|}{ : Pembelian bahan baku dan peralatan produksi. } \\
\hline & Inbound Logistic & Operation & Outbond Logistic & Marketing Sal es & Service \\
\hline $\begin{array}{l}\text { Penerimaan } \\
\text { Bahan Baku }\end{array}$ & $\begin{array}{l}\text { Pengangkutan dan } \\
\text { penerimaan bahan } \\
\text { baku dari } \\
\text { pemasok ke } \\
\text { tempat produksi. }\end{array}$ & $\begin{array}{l}\text { Penyimpanan } \\
\text { bahan baku. } \\
\text { Quality control } \\
\text { pada bahan baku. }\end{array}$ & $\begin{array}{l}\text { Pengumpul an } \\
\text { produk jadi dan } \\
\text { transfer produk } \\
\text { ke bagian } \\
\text { pengemasan. }\end{array}$ & & $\begin{array}{l}\text { Menjaga } \\
\text { hubungan baik } \\
\text { dengan pemasok. }\end{array}$ \\
\hline $\begin{array}{l}\text { Proses Produksi } \\
\text { Produk Batu } \\
\text { Marmer }\end{array}$ & $\begin{array}{l}\text { Penerimaan dan } \\
\text { pemil ahan bahan } \\
\text { baku sesuai } \\
\text { dengan kualitas } \\
\text { dan ukuran. }\end{array}$ & $\begin{array}{l}\text { Pengularan, } \\
\text { pembentukan, dan } \\
\text { dan pemolesan } \\
\text { produk batu } \\
\text { rmarmer yang } \\
\text { sudah jadi. }\end{array}$ & $\begin{array}{l}\text { Pro duk jadi } \\
\text { langsung dikemas } \\
\text { tanpa ada } \\
\text { penyimpanan } \\
\text { khusus. }\end{array}$ & & \\
\hline $\begin{array}{l}\text { Pengemasan } \\
\text { Produk Batu } \\
\text { Marmer }\end{array}$ & Pembelian kayu, & Pembuatan peti & $\begin{array}{l}\text { Pengemasan } \\
\text { menggunakan peti } \\
\text { dari kayu }\end{array}$ & $\begin{array}{l}\text { Penjualan dan } \\
\text { pemasaran produk } \\
\text { batu marmer di } \\
\text { wilayah lokal dan } \\
\text { mancanegara. }\end{array}$ & $\begin{array}{l}\text { Pengiriman tepat } \\
\text { Waktu. } \\
\text { Menjaga dan } \\
\text { memberikan } \\
\text { pelayanan terbaik } \\
\text { untuk pelanggan. } \\
\text { marmer }\end{array}$ \\
\hline
\end{tabular}

Gambar 1.2 Value Chain Home Industri Marmer Tulungagung (PRIMA) 


\begin{tabular}{|c|c|c|c|c|c|}
\hline Firm Infrastruktur & \multicolumn{5}{|c|}{ : Peralatan produksi (mesin potong, bor kecil, mesin bubut, mesin poles, dan gergaji berbagai ukuran). } \\
\hline $\begin{array}{l}\text { Human Resource } \\
\text { Management }\end{array}$ & \multicolumn{5}{|c|}{$\begin{array}{l}\text { Tenaga kerja terdiri dari tenaga kerja langsung dan tenaga kerja tidak langsung ( bagian administrasi, } \\
\text { pengawas bahan baku, dan sup ervisor). }\end{array}$} \\
\hline $\begin{array}{l}\text { Technology } \\
\text { Development }\end{array}$ & \multicolumn{5}{|c|}{ : Menggunakan peralatan modern dengan tenaga listrik. } \\
\hline Procurement & \multicolumn{5}{|c|}{ : Pembelian bahan baku dan peralatan produksi. } \\
\hline & Inbound Logistic & Operation & Outbond Logistic & Marketing Sales & Service \\
\hline $\begin{array}{l}\text { Penerimaan } \\
\text { Bahan Baku }\end{array}$ & $\begin{array}{l}\text { Pengangkutan dan } \\
\text { penerimaan bahan } \\
\text { baku dari } \\
\text { pemasok ke } \\
\text { tempat produksi. }\end{array}$ & $\begin{array}{l}\text { Penyimpanan } \\
\text { bahan baku. } \\
\text { Quality control } \\
\text { pada bahan baku. }\end{array}$ & $\begin{array}{l}\text { Pengumpulan } \\
\text { produk jadi dan } \\
\text { transfer produk } \\
\text { ke bagian } \\
\text { pengemasan. }\end{array}$ & & $\begin{array}{l}\text { Menjaga } \\
\text { hubungan baik } \\
\text { dengan pemasok. }\end{array}$ \\
\hline $\begin{array}{l}\text { Proses Produksi } \\
\text { Produk Batu } \\
\text { Marmer }\end{array}$ & $\begin{array}{l}\text { Penerimaan dan } \\
\text { pemilahan bahan } \\
\text { baku sesuai } \\
\text { dengan kualitas } \\
\text { dan ukuran. }\end{array}$ & $\begin{array}{l}\text { Pengukuran, } \\
\text { pembentukan, dan } \\
\text { dan pemolesan } \\
\text { produk batu } \\
\text { rmarmer yang } \\
\text { sudah jadi. }\end{array}$ & $\begin{array}{l}\text { Produk jadi } \\
\text { langsung dikemas } \\
\text { tanpa ada } \\
\text { penyimpanan } \\
\text { khusus. }\end{array}$ & & \\
\hline $\begin{array}{l}\text { Pengemasan } \\
\text { Produk Batu } \\
\text { Marmer }\end{array}$ & Pembelian kayu, & Pembuatan peti & $\begin{array}{l}\text { Pengemasan } \\
\text { menggunakan peti } \\
\text { dari kayu }\end{array}$ & $\begin{array}{l}\text { Penjualan dan } \\
\text { pemasaran produk } \\
\text { batu marmer di } \\
\text { wilayah lokal dan } \\
\text { mancanegara. }\end{array}$ & $\begin{array}{l}\text { Pengiriman tepat } \\
\text { Waktu. } \\
\text { Menjaga dan } \\
\text { memberikan } \\
\text { pelayanan terbaik } \\
\text { untuk pelanggan. } \\
\text { marmer }\end{array}$ \\
\hline
\end{tabular}

\subsection{Identifikasi Efektivitas dan Efisiensi Kegiatan}

\subsubsection{Efektivitas Kegiatan Industri Batu Piring Handycraft Jember (C.V Rahmat)}

Tabel 4.5 Penggolongan Aktivitas

\begin{tabular}{|c|c|c|c|c|}
\hline No & $\begin{array}{r}\text { Aktivitas } \\
\end{array}$ & RVA & BVA & NVA \\
\hline 1 & Pengangkutan Bahan Baku & & $7,000,000$ & \\
\hline 2 & Pengawasan & & 50,000 & \\
\hline 3 & Pemeriksaan dan Pemilahan Bahan Baku & 100,000 & & \\
\hline 4 & Penyimpanan Bahan Baku & & & - \\
\hline 5 & Penjualan & $49,671,225$ & & \\
\hline 6 & Pengemasan & $6,500,000$ & & \\
\hline 7 & Pengiriman & $12,000,000$ & & \\
\hline 8 & Pemrosesan Pesanan & - & & \\
\hline 9 & Penanganan Keluhan dan Ganti Rugi & $2,700,000$ & & \\
\hline 10 & Promosi nonformal & $2,483,561$ & & \\
\hline \multirow[t]{3}{*}{11} & Pemeriksaan Kualitas Produk & & & 150,000 \\
\hline & $\begin{array}{ll} & \text { Total } \\
\end{array}$ & $73,454,786$ & $7,050,000$ & 150,000 \\
\hline & Persentase & $91 \%$ & $9 \%$ & $0 \%$ \\
\hline
\end{tabular}


Aktivitas pada C.V Rahmat tiap 285 meter persegi produksi batu piring asimetris adalah 91\% termasuk aktivitas Real Value Added, yaitu aktivitas yang memberikan nilai tambah untuk pelanggan, sebesar 9\% termasuk aktivitas Bussiness Value Added, yaitu aktivitas yang memberikan nilai tambah untuk proses produksi dan $0 \%$ termasuk kegiatan Non Value Added, yaitu kegiatan yang tidak memebrikan nilai tambah bagi pelanggan dan perusahaan. Melalui analisis penggolongan aktivitas, dapat disimpulkan bahwa aktivitas yang dilakukan C.V Rahmat sudah efektif dan efisien karena tidak memiliki kegiatan Non Value Added.

\subsubsection{Efektivitas Kegiatan Industri Marmer Tulungagung (Home Industry)}

Tabel 4.9 Penggolongan Aktivitas

\begin{tabular}{|c|c|c|c|c|}
\hline No & Aktivitas & RVA & BVA & NVA \\
\hline 1 & Pengangkutan Bahan Baku & & $24,000,000$ & \\
\hline 2 & Pengawasan & & - & \\
\hline 3 & Pemeriksaan dan Pemilahan Bahan Baku & - & & \\
\hline 4 & Penyimpanan Produk Jadi & & & $1,000,000$ \\
\hline 5 & Penjualan & $90,000,000$ & & \\
\hline 6 & Pengemasan & $9,000,000$ & & \\
\hline 7 & Pengiriman & $3,000,000$ & & \\
\hline 8 & Pemrosesan Pesanan & - & & \\
\hline 9 & Penanganan Keluhan dan Ganti Rugi & - & & \\
\hline 10 & Promosi nonformal & - & & \\
\hline \multirow[t]{3}{*}{11} & Pemeriksaan Kualitas Produk & & & - \\
\hline & $\begin{array}{r}\text { Total } \\
\end{array}$ & $103,000,000$ & $24,000,000$ & $1,000,000$ \\
\hline & Persentase & $80 \%$ & $19 \%$ & $1 \%$ \\
\hline
\end{tabular}

Aktivitas pada Home Industri Tulungagung untuk 300 meter persegi produksi batu marmer adalah $80 \%$ termasuk aktivitas Real Value Added, yaitu aktivitas yang memberikan nilai tambah untuk pelanggan, sebesar 19\% termasuk aktivitas Bussiness Value Added, yaitu aktivitas yang memberikan nilai tambah untuk proses produksi dan $1 \%$ termasuk kegiatan Non Value Added, yaitu kegiatan yang tidak memberikan nilai tambah bagi pelanggan dan perusahaan. Melalui analisis penggolongan aktivitas, dapat disimpulkan bahwa aktivitas yang dilakukan Home Industry Tulungagung belum efektif dan efisien karena memiliki 1\% kegiatan Non Value Added.

Tabel 4.10 Analisis Porter (Persaingan Antar Perusahaan Sejenis)

\begin{tabular}{|l|l|l|l|}
\hline No & Indikator & Analisis & Kesimpulan \\
\hline 1. & Jumlah Pesaing & $\begin{array}{l}\text { Jumlah pesaing yang berada di } \\
\text { wilayah Kabupaten Jember terdapat 3 } \\
\text { perusahaan berskala kecil dan } \\
\text { menengah dan satu perusahaan } \\
\text { berskala besar. Serta terdapat banyak } \\
\text { pesaing skala home industry }\end{array}$ & Sedang \\
\hline 2. & $\begin{array}{l}\text { Peningkatan } \\
\text { Jumlah Pesaing }\end{array}$ & $\begin{array}{l}\text { Peningkatan pesaing banyak terjadi di } \\
\text { industri skala rumahan (home } \\
\text { industry). Sedangkan industri skala } \\
\text { UMKM hanya meningkat 1- 2 }\end{array}$ & Rendah \\
\hline
\end{tabular}




\begin{tabular}{|c|c|c|c|}
\hline & & $\begin{array}{l}\text { perusahaan baru per tahunnya. } \\
\text { Beberapa industri baru kebanyakan } \\
\text { hanya dapat bertahan sekitar 2-3 } \\
\text { tahun }\end{array}$ & \\
\hline 3. & $\begin{array}{l}\text { Diferensiasi } \\
\text { Produk dengan } \\
\text { Pesaing }\end{array}$ & $\begin{array}{l}\text { Industri batu piring umumnya tidak } \\
\text { memiliki diferensiasi produk namun } \\
\text { biasanya industri batu piring } \\
\text { mengolah limbah batu menjadi batu } \\
\text { koral. Diferensiasi produk hanya } \\
\text { sebatas pada unsur kerataan, } \\
\text { ketebalan, presisi ukuran serta } \\
\text { service/pelayanan yang diberikan } \\
\text { kepada konsumen }\end{array}$ & $\begin{array}{l}\text { Persaingan } \\
\text { Rendah }\end{array}$ \\
\hline 4. & $\begin{array}{l}\text { Diferensiasi } \\
\text { Bahan Baku }\end{array}$ & $\begin{array}{l}\text { Perusahaan batu piring menggunakan } \\
\text { bahan baku yang sama }\end{array}$ & $\begin{array}{l}\text { Persaingan } \\
\text { Rendah }\end{array}$ \\
\hline 5. & Biaya Produksi & $\begin{array}{l}\text { Kenaikan biaya bahan baku cukup } \\
\text { lambat sekitar 3-4 tahun sekali dan } \\
\text { kenaikannya sangat sedikit. Kenaikan } \\
\text { biaya produksi terbesar dipicu oleh } \\
\text { kenaikan UMR (Upah Minimum } \\
\text { Regional) para pekerja }\end{array}$ & $\begin{array}{l}\text { Persaingan } \\
\text { Rendah }\end{array}$ \\
\hline
\end{tabular}

Tabel 4.11 Analisis Porter (Ancaman Pendatang Baru)

\begin{tabular}{|c|c|c|c|}
\hline No & Indikator & Analisis & Kesimpulan \\
\hline 1. & Kebutuhan modal & $\begin{array}{l}\text { Kebutuhan modal untuk membuka } \\
\text { bisnis produk batu piring } \\
\text { tergolong mahal. Keseluruhan } \\
\text { modal tersebut digunakan untuk } \\
\text { membeli mesin, peralatan, dan } \\
\text { pembangunan tempat usaha. }\end{array}$ & $\begin{array}{l}\text { Ancaman } \\
\text { rendah. }\end{array}$ \\
\hline 2. & $\begin{array}{l}\text { Cara mencukupi } \\
\text { kebutuhan modal }\end{array}$ & $\begin{array}{l}\text { Untuk mencukupi kebutuhan } \\
\text { modal tersebut dilakukan dengan } \\
\text { penagihan uang muka pada } \\
\text { pembeli dan pinjaman eksternal. }\end{array}$ & $\begin{array}{l}\text { Ancaman } \\
\text { rendah. }\end{array}$ \\
\hline 3. & $\begin{array}{ll}\text { Tingkat } & \text { loyalitas } \\
\text { pelanggan } & \end{array}$ & $\begin{array}{l}\text { Tingkat loyalitas pelanggan } \\
\text { bergantung pada kecocokan } \\
\text { konsumen dengan perusahaan } \\
\text { tersebut. Sejauh ini perusahaan } \\
\text { telah memiliki banyak pelanggan } \\
\text { dalam negeri maupun luar negeri. }\end{array}$ & $\begin{array}{l}\text { Ancaman } \\
\text { rendah. }\end{array}$ \\
\hline
\end{tabular}




\begin{tabular}{|c|c|c|c|}
\hline 4. & $\begin{array}{l}\text { Terbentuknya } \\
\text { loyalitas pelanggan }\end{array}$ & $\begin{array}{l}\text { Loyalitas pelanggan tidak } \\
\text { terbentuk dengan sendirinya, } \\
\text { melainkan karena pelayanan dan } \\
\text { kinerja yang baik dari perusahaan. } \\
\text { Sejauh ini perusahaan telah } \\
\text { berkomitmen untuk terus } \\
\text { memenuhi kebutuhan pelanggan } \\
\text { dan berusaha untuk menjaga } \\
\text { hubungan baik } \\
\text { komunikasi sehingga dapat } \\
\text { memuaskan pelanggan. }\end{array}$ & $\begin{array}{l}\text { Ancaman } \\
\text { rendah. }\end{array}$ \\
\hline 5. & $\begin{array}{ll}\text { Akses ke saluran } \\
\text { distribusi }\end{array}$ & $\begin{array}{l}\text { Perusahaan produk batu piring } \\
\text { memiliki hubungan kerja sama } \\
\text { dengan pihak terkait pengiriman } \\
\text { produk. }\end{array}$ & $\begin{array}{l}\text { Ancaman } \\
\text { rendah. }\end{array}$ \\
\hline 6. & $\begin{array}{l}\text { Kebutuhan biaya ke } \\
\text { saluran distribusi }\end{array}$ & $\begin{array}{l}\text { Biaya yang digunakan bergantung } \\
\text { pada kebijakan (fob shipping atau } \\
\text { fob destination) dan jarak } \\
\text { distribusi. }\end{array}$ & $\begin{array}{l}\text { Ancaman } \\
\text { sedang. }\end{array}$ \\
\hline 7. & Kebijakan pemerintah & $\begin{array}{lr}\text { Pertumbuhan } & \text { industri tidak } \\
\text { terlepas dari r kebijakan } \\
\text { pemerintah, } & \text { dikarenakan } \\
\text { pemerintah telah mempermudah } \\
\text { perijinan dan pengkondisian } \\
\text { sektor industri untuk tumbuh. }\end{array}$ & $\begin{array}{l}\text { Ancaman } \\
\text { tinggi. }\end{array}$ \\
\hline 8. & $\begin{array}{ll}\text { Dampak kebijakan } \\
\text { pemerintah }\end{array}$ & $\begin{array}{l}\text { Kabijakan pemerintah memiliki } \\
\text { dampak cukup besar. }\end{array}$ & $\begin{array}{l}\text { Ancaman } \\
\text { tinggi. }\end{array}$ \\
\hline
\end{tabular}

Tabel 4.12 Analisis Porter (Ancaman Produk Substitusi)

\begin{tabular}{|l|l|l|l|}
\hline No. & Indikator & Analisis & Kesimpulan \\
\hline 1. & $\begin{array}{l}\text { Tingkat kebutuhan } \\
\text { terhadap produk } \\
\text { pengganti }\end{array}$ & $\begin{array}{l}\text { Tingkat kebutuhan terhadap produk } \\
\text { pengganti sedang dimana ada produk } \\
\text { yang lebih memiliki keunikan } \\
\text { tersendiri }\end{array}$ & $\begin{array}{l}\text { Ancaman } \\
\text { sedang }\end{array}$ \\
\hline 2. & $\begin{array}{l}\text { Kemudahan } \\
\text { mendapatkan } \\
\text { produk pengganti }\end{array}$ & $\begin{array}{l}\text { Kemudahan mendapatkan produk } \\
\text { pengganti sekitar 45\% }\end{array}$ & $\begin{array}{l}\text { Kekuatan } \\
\text { penawaran } \\
\text { pemasok } \\
\text { sedang }\end{array}$ \\
\hline
\end{tabular}

Tabel 4.13 Analisis Porter (Kekuatan Tawar Menawar Pembeli)

\begin{tabular}{|l|l|c|c|}
\hline No & Indikator & Analisis & Kesimpulan \\
\hline
\end{tabular}




\begin{tabular}{|c|c|c|c|}
\hline 1. & $\begin{array}{l}\text { Tingkat dominasi } \\
\text { pembeli }\end{array}$ & $\begin{array}{l}\text { Pembeli didominasi oleh agen atau } \\
\text { distributor produk batu piring dan } \\
\text { pembeli mancanegara (ekspor). }\end{array}$ & $\begin{array}{l}\text { Kekuatan } \\
\text { tawar } \\
\text { menawar } \\
\text { pembeli } \\
\text { tinggi. }\end{array}$ \\
\hline 2. & $\begin{array}{l}\text { Dominasi pembeli } \\
\text { tiap tahun }\end{array}$ & $\begin{array}{l}\text { Dominasi pembeli tidak konstan, } \\
\text { tergantung pada jumlah permintaan } \\
\text { produk batu piring. }\end{array}$ & $\begin{array}{l}\text { Kekuatan } \\
\text { tawar } \\
\text { menawar } \\
\text { pembeli } \\
\text { sedang. }\end{array}$ \\
\hline 3. & $\begin{array}{l}\text { Dampak biaya } \\
\text { peralihan produk }\end{array}$ & $\begin{array}{l}\text { Besarnya dampak biaya peralihan } \\
\text { produk bergantung pada nilai yang ada } \\
\text { pada peralihan tersebut. Biaya } \\
\text { peralihan }<5 \text { juta rendah, 5-10 juta } \\
\text { sedang, 10-20 juta tinggi. Perusahaan } \\
\text { CV.Rahmat termasuk perusahaan yang } \\
\text { minim dalam mengeluarkan biaya } \\
\text { peralihan. }\end{array}$ & $\begin{array}{l}\text { Kekuatan } \\
\text { tawar } \\
\text { menawar } \\
\text { pembeli } \\
\text { sedang. }\end{array}$ \\
\hline 4. & $\begin{array}{lr}\text { Dana } & \text { cadangan } \\
\text { untuk } & \text { biaya } \\
\text { peralihan produk }\end{array}$ & $\begin{array}{l}\text { Dana cadangan }<5 \text { juta rendah, } 5-10 \\
\text { juta sedang, } 10-20 \text { juta tinggi. } \\
\text { Perusahaan memiliki tingkat dana } \\
\text { cadangan yang rendah untuk biaya } \\
\text { peralihan produk. }\end{array}$ & $\begin{array}{l}\text { Kekuatan } \\
\text { tawar } \\
\text { menawar } \\
\text { pembeli } \\
\text { sedang. }\end{array}$ \\
\hline 5. & $\begin{array}{l}\text { Tingkat kejelasan } \\
\text { informasi produk }\end{array}$ & $\begin{array}{l}\text { Spesifikasi produk tidak diuraikan } \\
\text { secara rinci, karena produk batu piring } \\
\text { merupakan barang komoditas. }\end{array}$ & $\begin{array}{l}\text { Kekuatan } \\
\text { tawar } \\
\text { menawar } \\
\text { pembeli } \\
\text { rendah. }\end{array}$ \\
\hline 6. & $\begin{array}{l}\text { Izin resmi dari } \\
\text { informasi produk }\end{array}$ & $\begin{array}{l}\text { Informasi produk tidak memiliki izin } \\
\text { resmi. }\end{array}$ & $\begin{array}{l}\text { Kekuatan } \\
\text { tawar } \\
\text { menawar } \\
\text { pembeli } \\
\text { rendah. }\end{array}$ \\
\hline 7. & \begin{tabular}{lr}
\multicolumn{2}{l}{ Pertumbuhan } \\
pangsa pasar \\
pembeli tiap \\
periode
\end{tabular} & $\begin{array}{l}\text { Pertumbuhan pangsa pasar sekitar } 5 \% \\
-10 \% \text {. }\end{array}$ & $\begin{array}{l}\text { Kekuatan } \\
\text { tawar } \\
\text { menawar } \\
\text { pembeli } \\
\text { tinggi. }\end{array}$ \\
\hline 8. & $\begin{array}{l}\text { Pangsa pasar } \\
\text { pembeli tiap tahun }\end{array}$ & $\begin{array}{l}\text { Pangsa pasar pembeli tidak konstan } \\
\text { tergantung dari tingkat daya beli } \\
\text { konsumen. }\end{array}$ & $\begin{array}{l}\text { Kekuatan } \\
\text { tawar } \\
\text { menawar } \\
\text { pembeli } \\
\text { tinggi. }\end{array}$ \\
\hline
\end{tabular}


Tabel 4.14 Analisis Porter (Kekuatan Tawar Menawar Pemasok)

\begin{tabular}{|l|l|l|l|}
\hline No. & Indikator & Analisis & Kesimpulan \\
\hline 1. & $\begin{array}{l}\text { Tingkat dominasi } \\
\text { pemasok }\end{array}$ & $\begin{array}{l}\text { Pemasok tidak didominasi oleh hanya } \\
\text { satu pemasok }\end{array}$ & $\begin{array}{l}\text { Kekuatan } \\
\text { pemasok } \\
\text { rendah }\end{array}$ \\
\hline 2. & $\begin{array}{l}\text { Alternatif } \\
\text { pemasok }\end{array}$ & $\begin{array}{l}\text { Perusahaan memiliki 4 daerah } \\
\text { pemasok yaitu terdapat 4 bukit yang } \\
\text { terdapat beberapa penambang setiap } \\
\text { bukitnya untuk memasok bahan baku }\end{array}$ & $\begin{array}{l}\text { Kekuatan } \\
\text { penawaran } \\
\text { pemasok } \\
\text { rendah }\end{array}$ \\
\hline 3. & $\begin{array}{l}\text { Tingkat kualitas } \\
\text { produk pemasok }\end{array}$ & $\begin{array}{l}\text { Kualitas produk dari pemasok tidak } \\
\text { memiliki standar yang harus dipenuhi } \\
\text { oleh pemasok }\end{array}$ & $\begin{array}{l}\text { Kekuatan } \\
\text { penawaran } \\
\text { pemasok } \\
\text { rendah }\end{array}$ \\
\hline 4. & $\begin{array}{l}\text { Kekuatan dari } \\
\text { produk pemasok } \\
\text { selalu konstan }\end{array}$ & $\begin{array}{l}\text { Kualitas produk selalu konstan karena } \\
\text { apapun bentuknya dan jumlahnya dari } \\
\text { penambang akan diterima oleh } \\
\text { perusahaan. }\end{array}$ & $\begin{array}{l}\text { Kekuatan } \\
\text { penawaran } \\
\text { pemasok } \\
\text { rendah }\end{array}$ \\
\hline 5. & $\begin{array}{l}\text { Tingkat } \\
\text { persaingan pasar } \\
\text { pemasok }\end{array}$ & $\begin{array}{l}\text { Tidak terdapat persaingan pasar } \\
\text { pemasok }\end{array}$ & $\begin{array}{l}\text { Kekuatan } \\
\text { penawaran } \\
\text { pemasok } \\
\text { rendah }\end{array}$ \\
\hline 6. & $\begin{array}{l}\text { Persaingan pasar } \\
\text { pemasok selalu } \\
\text { netral }\end{array}$ & Persaingan pasar pemasok netral & $\begin{array}{l}\text { Kekuatan } \\
\text { penawaran } \\
\text { pemasok } \\
\text { rendah }\end{array}$ \\
\hline 7. & $\begin{array}{l}\text { Besarnya biaya } \\
\text { beralih ke } \\
\text { pemasok lain }\end{array}$ & $\begin{array}{l}\text { Tidak terdapat biaya peralihan karena } \\
\text { harga bahan baku dari waktu kewaktu } \\
\text { hampir sama dan sudah ditetapkan } \\
\text { perusahaan }\end{array}$ & $\begin{array}{l}\text { Kekuatan } \\
\text { penawaran } \\
\text { pemasok } \\
\text { rendah }\end{array}$ \\
\hline 8. & $\begin{array}{l}\text { Biaya peralihan } \\
\text { pemasok tiap } \\
\text { tahun }\end{array}$ & Tidak terdapat biaya peralihan & $\begin{array}{l}\text { Kekuatan } \\
\text { penawaran } \\
\text { pemasok } \\
\text { rendah }\end{array}$ \\
\hline
\end{tabular}

\subsection{Analisis Kekuatan Porter dan Perumusan Strategi}

4.4.1. Analisis 5 Kekuatan Porter (5 Porter's Force)

Pada penelitian ini, penulis menggunakan metode 5 kekuatan porter sebagai 
metode untuk perumusan strategi. Hasil analisis yang ditunjukkan pada lampiran 2 (tabel 4.10, 4.11, 4.12, 4.13, 4.14) menunjukkan bahwa kekuatan perusahaan dianalisis menjadi 5 kekuatan diantaranya persaingan antar perusahaan sejenis, ancaman pendatang baru, ancaman produk substitusi, kekuatan tawar menawar pembeli dan pemasok.

Berdasarkan hasil analisis dalam (tabel 4.10, 4.11, 4.12, 4.13, 4.14), didapatkan hasil bahwa industri batu piring bahwa terdapat 4 indikator yang tidak berpengaruh dan 1 indikator yang berpengaruh ssignifikan terhadap kelangsungan usaha pada industri batu piring. Indikator yang tidak terlalu signifikan terhadap kelangsungan usaha pada industri batu piring adalah persaingan antar perusahaan sejenis, ancaman pendatang baru, produk substitusi, dan kekuatan tawar menawar pemasok. Beberapa indikator tersebut tidak berpengaruh signifikan karena sebagian besar poin pada uraian masing-masing tabel menunjukkan hasil yang rendah untuk menjadi ancaman pada industri batu piring. Sedangkan pada indikator kekuatan tawar-menawar pembeli menunjukkan hasil yang tinggi. Sehingga dapat disimpulkan dari 5 kekuatan porter tersebut yang menjadi faktor kunci adalah kekuatan tawarmenawar pembeli.

\subsubsection{Perumusan Strategi Baru}

- Strategi Struktural : Industri batu piring memiliki struktur pasar monopolistik yang terfragmentasi. Strategi yang dapat dilakukan adalah melakukan tindakan kooperatif dengan bekerjasama dengan industri batu alam lain guna membentuk inovasi produk baru dan memperkecil fragmentasi pasar. Strategi lain yang cocok diterapkan pada struktur monopolistik adalah menentukan target marketing yaitu fokus pada konsumen kalangan menengah keatas dan masyarakat luar negeri. Melakukan tindakan ofensif dan defensif dengan cara meningkatkan pelayanan konsumen serta meningkatkan promosi produk menggunakan teknik word of mouth.

- Strategi Generik: Hasil dari analisis strategi generik adalah fokus kepada diferensiasi jasa layanan konsumen untuk membangun citra baik perusahaan, mempertahankan konsumen lama (pelanggan) serta mendukung kegiatan promosi teknik word of mouth melalui testimony pelanggan kepada calon konsumen baru. Tindakan fokus juga diterapkan dalam pemilihan segmentasi pasar yaitu pada masyarakat kalangan menengah keatas dan pasar internasional yang memiliki tawaran harga yang lebih tinggi. Kegiatan diferensiasi jasa layanan konsumen akan memperkecil kebutuhan akan posisi biaya rendah.

- Strategi Terhadap Pembeli dan Pemasok : Poin terpenting dalam seleksi pembeli adalah meningkatkan pelayanan dan hubungan baik dengan konsumen untuk memperkecil kekuatan tawar-menawar pembeli dan 
memperluas area pemasaran untuk menaeik konsumen baru. Sedangkan strategi pembelian meliputi pembelian bahan baku pada pemasok yang berbeda dan menerapkan standarisasi bahan baku untuk menghindari biaya peralihan dan mengurangi kekuatan tawar-menawar pemasok.

- Strategi Terhadap Ancaman Barang Subtitusi dan Pendatang Baru: Melakukan tindakan ofensif dengan cara menjalin kerjasama dan memproduksi produk inovasi baru, menjaga kerahasiaan perusahaan dan bersikap merendah untuk membingungkan pesaing dalam menentukan strategi awal. Sedangkan tindakan defensife meliputi displin dalam proses pengerjaan dan pengiriman guna meningkatkan kepuasan konsumen dan menjaga citra baik perusahaan. Serta melakukan tindakan peniadaan basis melalui kegiatan investasi dalam jumlah besar dan penurunan harga produk untuk membuat hambatan bagi perusahaan baru sehingga dengan sendirinya akan mengundurkan diri dari pasar.

\subsection{Kesimpulan}

\section{BAB V. PENUTUP}

Berdasarkan analisis menggunakan model 5 Porter's Force, penurunan produktivitas batu piring handycraft Kabupaten Jember diakibatkan oleh turunnya permintaan domestik maupun internasional. Penurunan permintaan disebabkan oleh kegiatan produksi yang tidak efisien serta kurangnya kemampuan bersaing sehingga mengakibatkan banyak perusahaan baru mengalami kebangkrutan. Produktivitas dapat ditingkatkan kembali melalui penerapan strategi bersaing yang dirumuskan berdasarkan model 5 Porter's Forces. Adapun strategi yang diperlukan perusahaan batu piring handycraft Jember dibagi menjadi 4 rumusan strategi yaitu (1) strategi struktural yang menentukan posisi perusahaan didalam pasar, (2) strategi generic yang merupakan strategi internal perusahaan meliputi keunggulan biaya, diferensiasi dan fokus pada kegiatan value added konsumen. Kemudian, (3) strategi terhadap pembeli yang meliputi strategi seleksi pembeli melalui target marketing guna mengefisiensi biaya promosi serta mengurangi kekuatan bargaining konsumen dan melalui strategi pembelian guna mengurangi bargaining pemasok. (4) strategi terhadap ancaman produk subtitusi dan new entrant meliputi gerakan ofensif dan defensive yang berguna mempertahankan posisi perusahaan dan membangun hambatan masuk bagi perusahaan pendatang baru.

\subsection{Saran}

\section{Bagi Industri Batu Piring}

Sebaiknya para pelaku usaha batu piring handycraft meningkatkan kekuatan bersaing dengan mempersiapkan strategi yang dituangkan dalam langkah-langkah strategis yang disusun secara sistematis agar dapat bersaing dengan perusahaan batu piring bahkan batu alam lain seperti marmer dan batu hitam. Strategi yang telah dirumuskan didalam 
penelitian ini dapat disesuaikan dengan kondisi perusahaan yang memiliki spesifikasi masalah yang berbeda-beda. Disarankan untuk menentukan target konsumen pada segmen masyarakat berpendapatan tinggi dan masyarakat luar negeri serta memperbaiki pelayanan konsumen yang nantinya akan meningkatkan potensi pertumbuhan pembeli.

\section{Bagi Pemerintah Kabupaten Jember}

Berdasarkan hasil pembandingan industri batu piring dan batu marmer tulungagung, batu piring memiliki potensi yang sama besarnya dengan batu alam lain (khususnya marmer). Sehingga perlu adanya dukungan berupa integrasi industri batu piring agar produktivitas dapat meningkat dan menjadi salah satu faktor penyumbang PDRB terbesar di Kabupaten Jember. Batu piring juga dapat menjadi ikon dan ciri khas Kabupaten Jember dan dapat dikembangkan menjadi daya tarik bagi investor maupun wistawan mancanegara. Dukungan pemerintah berupa penyelenggaraan pameran produk asli Kabupaten Jember yang melibatkan produk batu piring handycraft akan membantu meningkatkan produktivitas dari segi promosi.

\section{DAFTAR PUSTAKA}

Arsyad, L., \& Kusuma, S. E. (2014). Ekonomika Industri Pendekatan Struktur, Perilaku, dan Kinerja. Yogyakarta: UPP STIM YKPN.

Astutik, L. T. (2015). Pemetaan Pola Sebaran Gumuk Menggunakan Metode Sisitem Informasi Geografis di kabupaten Jember. Kabupaten Jember : Universitas Jember.

Aw, B. Y., \& Lee, Y. (2017). Demand, Costs and Product Scope in the Export Market. European Economic Review, 1-38.

BPS Kabupaten Jember. (2010-2016). Kabupaten jember dalam angka 2015. Kabupaten Jember : BPS Kabupaten Jember.

Candra, Sevenpri. (2013). Aplikasi Model Lima Kekuatan Porter Pada Restoran Drupadi. BINUS BUSINESS REVIEW Vol. 4 No. 1 Mei 2013: 398-404

Fathia, A., \& Ahmadian, S. (2016). Competitiveness of the Iran Automotive Industry for Entrancing into Foreign Markets. Procedia Economics and Finance SCIJOUR-Scientific , 29-31.

Kritzinger, I., Lotze, E., \& Jooste, M. (2016). Stone hardening and broken stones in Japanese plums (Prunus salicina Lindl.) evaluated by means of computed tomography scans. Scientia Horticulturae, 1-9. 
L, M., Dey, P., V, G., Sluyter, P., E, J., \& Keating, B. (1994). Statistical Process Control and Direct Care Staff Performance. The Journal of Mental Health Administration, 201-208.

Mangifera. L. (2015). Analisis Rantai (Value Chain) pada Produk Batik Tulis Surakarta. Surakarta. Jurnal Managemen dan Bisnis. Vol. 19. No. 1: 24-33.

Mould, D., \& Rosin, P. L. (2017). Developing and applying a benchmark for evaluating image stylization. Computers \& Graphics, 1-2.

Novandari, Weni. (2013). Pemetaan Dan Analisis Kompetensi Inti Ukm Batik Di Kabupaten Purbalingga Dengan Pendekatan Value Chain. Jurnal Ekonomi dan Bisnis. Volume 12. Nomor 01.

Gesah, R., \& Prabowo, M. (2019). Manajemen Strategi Penulis: Rachmad Gesah Mukti Prabowo. INA-Rxiv Paper.

Porter, M. E. (2008). Strategy Strategy the Five Competitive. Harvard Business Review, 86(January), 78-94.

Porter, Michael E. (1980). Strategi Bersaing: Teknik Menganalisis Industri dan Pesaing. Jakarta: Erlangga

Porter, Michael E. (1985). Competitive Advantage: Creating and Sustaining Superior Performance. New York: The Free Press.

Rodrigues. F., Torssonen. P., Saominen. S., Pitkanen., S.2017, Fuelwood Value Chain Analysis in Cassou and Ouagadougou, Burkina Faso: From Production to consumption. Joensuu. Energy for Sustainable Development. Vol 41: 1423.

Roosta, R. A., Moghaddasi, R., \& Hosseini, S. S. (2017). Export target markets of medicinal and aromatic plants. Journal of Applied Research on Medicinal and Aromatic, 1-2.

Rosales, M. et. al. 2017. Value Chain Analysis and Small-scale Fisheries Management. Pasay City. Marine Policy. Vol 83: 11-21.

Svarova, Monika., Vrchota, Jaroslav. (2014). Influence of competitive advantage on formulation business strategy. Procedia Economics and Finance 12 ( 2014 ) $687-694$. 
Wibowo, H. A., Suhartono, \& Wahyuni, S. (2013). Inovasi Produk Batu Alam Dalam Upaya Peningkatkan Volume Penjualan Pada Cv Superindo Abadi Jember (Innovation Products of Natural Stone in an Effort To Increase Sales Volume at CV Superindo Abadi Jember). Administrasi Bisnis, Fakultas Ilmu Sosial dan Ilmu Politik, Universitas Jember (UNEJ), 1.

Wisdaningrum, Oktavima. (2013). Analisis Rantai Nilai (Value Chain) dalam Lingkungan Internal Perusahaan. ANALISA, Vol. 1, No. 1, April 2013: 40 - 48 


\section{Lampiran 1}

Gambar 1.3 Skema Penentuan Strategi Kinerja Industi Batu Piring

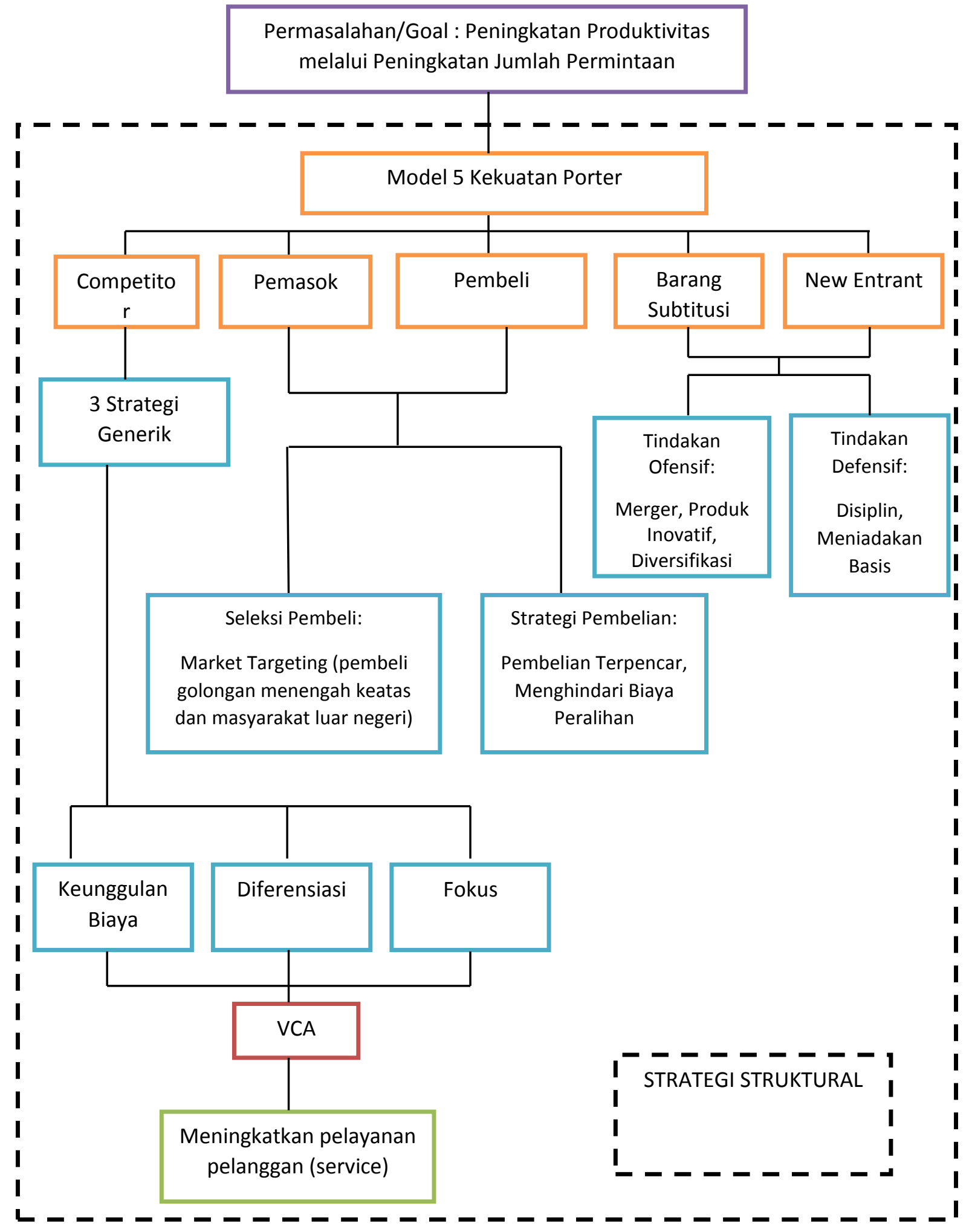


Keterangan Warna:

- Garis Warna Ungu =Permasalahan yang akan diselesaikan sekaligus menjadi goal/tujuan penentuan strategi

- Garis Warna Jingga = Faktor yang mempengaruhi adanya permasalahan yaitu analisis model 5 kekuatan porter (5 Porter's Forces)

- Garis Warna Biru = Jenis-jenis strategi yang dapat dilakukan sesuai dengan kondisi faktor-faktor persaingan (5 komponen Porter's Forces)

- Garis Warna Merah = Jenis alat analisis yang menguraikan strategi biaya dan kegiatan strategis

- Garis Warna Hijau = Strategi paling dominan/ strategi utama

- Garis Hitam Putus-Putus $=$ Faktor penentu utama penerapan strategi

- Strategi Struktural

\begin{tabular}{|l|l|l|}
\hline No & \multicolumn{1}{|c|}{ Hasil Analisis } & \multicolumn{1}{|c|}{ Langkah- Langkah Strategis } \\
\hline 1. & Karakteristik Pasar Monopolistik & $\begin{array}{l}\text { Melakukan tindakan seleksi pembeli } \\
\text { dan menentukan marketing target } \\
\text { sesuai dengan segmentasi pasar. } \\
\text { Dalam hal ini, segmentasi pasar yang } \\
\text { dituju adalah masyarakat kalangan } \\
\text { menengah keatas. }\end{array}$ \\
\hline Produk Terdiferensiasi & Terdapat banyak penjual dan pembeli \\
& Free entry-exit & $\begin{array}{l}\text { Melakukan tindakan defensif dengan } \\
\text { cara meningkatkan biaya pelayanan } \\
\text { (service) serta menerapkan standar } \\
\text { produk yang lebih baik dari } \\
\text { sebelumnya }\end{array}$ \\
\hline Promosi & $\begin{array}{l}\text { Melakukan tindakan/ gerakan ofensif } \\
\text { dengan cara membangun kerjasama } \\
\text { (merger) dengan perusahaan batu } \\
\text { piring/ batu alam lain yang akan } \\
\text { memunculkan inovasi produk baru } \\
\text { dari kombinasi beberapa jenis batu } \\
\text { alam }\end{array}$ \\
\hline
\end{tabular}




\begin{tabular}{|l|l|}
\hline & $\begin{array}{l}\text { yang biasa dikenal dengan } \\
\text { penyampaian testimony dari mulut ke } \\
\text { mulut }\end{array}$ \\
\hline
\end{tabular}

- Strategi Generik

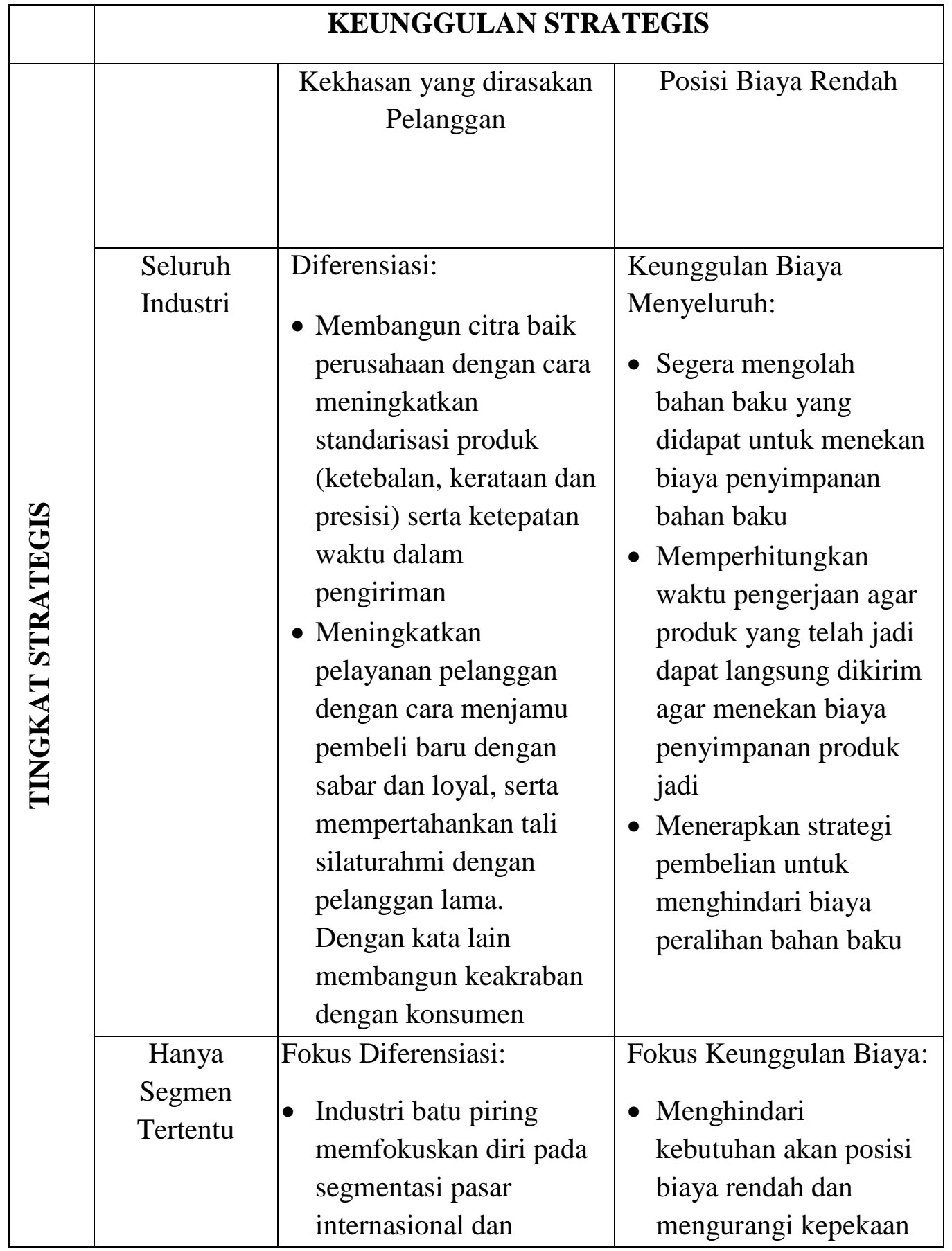




\begin{tabular}{|l|l|l|l|}
\hline & $\begin{array}{l}\text { masyarakat kalangan } \\
\text { menengah keatas }\end{array}$ & $\begin{array}{l}\text { pembeli terhadap harga } \\
\text { dengan melakukan } \\
\text { diferensiasi jasa }\end{array}$ \\
\hline
\end{tabular}

- Strategi Terhadap Pembeli dan Pemasok

\begin{tabular}{|c|c|c|}
\hline \multicolumn{3}{|r|}{ STRATEGI SELEKSI PEMBELI } \\
\hline No. & Kriteria Umum & Uraian Strategi \\
\hline 1 & $\begin{array}{l}\text { Kebutuhan Pembeli } \\
\text { vs Kemampuan } \\
\text { Perusahaan }\end{array}$ & $\begin{array}{l}\text { - } \text { Mengatur jadwal produksi sehingga dapat } \\
\text { memenuhi pesanan konsumen } \\
\text { - Tegas dalam mengambil keputusan dalam } \\
\text { penerimaan pesanan. Ketahui kapasitas produksi } \\
\text { perusahaan dan berani menolak pesanan diluar } \\
\text { kemampuan kapasitas produksi perusahaan. }\end{array}$ \\
\hline 2 & $\begin{array}{l}\text { Potensi } \\
\text { Pertumbuhan }\end{array}$ & $\begin{array}{l}\text { - Potensi pertumbuhan pembeli sekitar 5-10\% per } \\
\text { tahun masuk kedalam kategori rendah sehingga } \\
\text { perusahaan dapat menjaga kualitas pelayanan } \\
\text { kepada pelanggan untuk mempertahankan } \\
\text { pelanggan lama dan mampu menarik minat } \\
\text { konsumen baru. } \\
\text { - Memperluas area pemasaran untuk menarik } \\
\text { konsumen baru }\end{array}$ \\
\hline 3 & Posisi Struktural & $\begin{array}{l}\text { - Fokus pada pelayanan konsumen terbaik } \\
\text { berdasarkan loyalitas dan kekeluargaan untuk } \\
\text { menekan kekuatan tawar-menawar pembeli }\end{array}$ \\
\hline 4 & Biaya Pelayanan & $\begin{array}{l}\text { - Menjalin kerjasama dengan ekspedisi pengiriman } \\
\text { agar mendapatkan kualitas pengiriman tinggi } \\
\text { (tepat waktu dan minim kerusakan) dengan biaya } \\
\text { yang rendah } \\
\text { Menerima pesanan khusus. Misalnya: } \\
\text { menyanggupi permintaan batu piring berbentuk } \\
\text { heksagon, segitiga, pentagon dan bentuk lain yang } \\
\text { diinginkan konsumen } \\
\text { - Hindari menggunakan jasa distributor untuk } \\
\text { menekan biaya service dan memperkecil } \\
\text { kemungkinan kehilangan pelanggan lama. }\end{array}$ \\
\hline
\end{tabular}

\section{STRATEGI PEMBELIAN}

1. Pembelian Terpencar 
Membeli bahan baku dari pemasok yang berbeda guna meningkatkan posisi tawar-menawar perusahaan dan memperkecil kekuatan pemasok untuk menaikkan harga bahan baku. Pemencaran area pembelian sebaiknya jangan terlalu luas karena tidak akan menguntungkan dalam posisi struktural. Hindari membeli dari satu pemasok saja karena akan menimbulkan biaya peralihan yang besar.

2. Menghindari Biaya Peralihan

Membeli bahan baku dari beberapa pemasok berbeda akan meniadakan biaya peralihan. Yaitu biaya yang timbul akibat berganti pemasok. Biaya peralihan dapat berupa selisih harga bahan baku pada pemasok lama dengan harga bahan baku di pemasok baru. Meningkatkan standarisasi bahan baku juga dianjurkan untuk melumpuhkan biaya peralihan serta memastikan perusahaan mendapatkan kualitas bahan baku terbaik dengan harga yang sama.

- Strategi Terhadap Ancaman Barang Subtitusi dan Pendatang Baru

\begin{tabular}{|c|c|c|}
\hline \multicolumn{3}{|c|}{ GERAKAN BERSAING } \\
\hline & $\begin{array}{l}\text { Ancaman Barang } \\
\text { Subtitusi }\end{array}$ & $\begin{array}{l}\text { Ancaman Pendatang } \\
\text { Baru }\end{array}$ \\
\hline Tindakan Ofensif & $\begin{array}{l}\text { - Menjalin kerjasama } \\
\text { dengan perusahaan } \\
\text { batu alam lain seperti } \\
\text { marmer untuk } \\
\text { membangun inovasi } \\
\text { produk baru berupa } \\
\text { mozaik kombinasi } \\
\text { batu piring dengan } \\
\text { marmer, batu hitam } \\
\text { atau batu bondowoso }\end{array}$ & 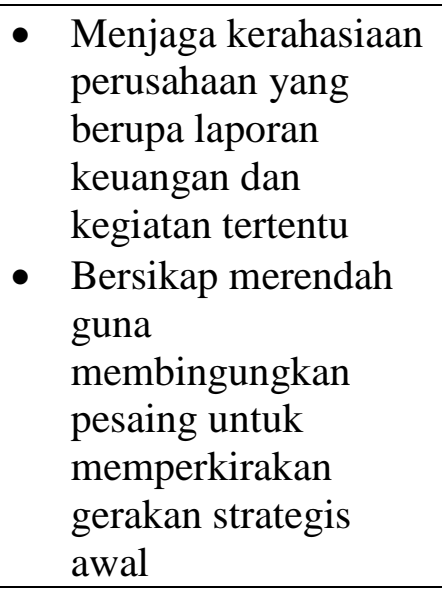 \\
\hline Tindakan Defensif & $\begin{array}{l}\text { Meningkat kualitas } \\
\text { produk berdasarkan } \\
\text { kerataan, ketebalan, } \\
\text { presisi dan kesesuaian } \\
\text { dengan keinginan } \\
\text { pembeli }\end{array}$ & $\begin{array}{l}\text { - Disiplin dalam proses } \\
\text { produksi hingga } \\
\text { proses pengiriman. } \\
\text { Sehingga kepuasan } \\
\text { konsumen dapat } \\
\text { tercapai secara } \\
\text { optimal dan } \\
\text { menambah citra baik } \\
\text { perusahaan } \\
\text { - Meniadakan basis } \\
\text { dengan taktik } \\
\text { pengadaan biaya }\end{array}$ \\
\hline
\end{tabular}




\begin{tabular}{|l|l|}
\hline & \multicolumn{1}{|c|}{ investasi yang besar } \\
dan penurunan biaya \\
produk. Hal ini akan \\
membuat hambatan \\
besar bagi pendatang \\
& baru dan akhirnya \\
& perusahaan baru \\
& memutuskan untuk \\
& mengundurkan diri \\
& (tutup usaha secara \\
& sukarela) \\
\hline
\end{tabular}

